\title{
The Negotiation of Political Identity and Rise of Social Citizenship: A Study of the Former Female Combatants in Aceh Since the Helsinki Peace Accord
}

\author{
Arifah Rahmawati; Dewi H Susilastuti; Mohtar Mas'oed; Muhadjir Darwin \\ Universitas Gadjah Mada, Indonesia \\ Coresponding Author: arifah1213@yahoo.com
}

\begin{abstract}
An identity negotiation process, initiated after the peace agreement was reached, is currently underway in Aceh. This can be seen, for example, in the activities of the women joined in the Inong Balee troop, the women's wing of the Free Aceh Movement (Gerakan Aceh Merdeka, GAM) formed in the late 1990s. Their participation as women combatants is inseparable from the strong ethno-nationalistic identity and ethno-political struggle that sought Aceh's independence. Today, more than twelve years after peace was reached in Aceh, the Acehnese ethno-political identity has experienced a transformation. Although it has not entirely disappeared, their activities have been framed as part of Indonesian nationalism. This finding emphasizes that nation is not fixed, but transformable and negotiable. The once ethno-political identity has become a social national identity. This paper attempts to understand how former woman members of GAM through a qualitative narrative. This paper attempts to answer why this has happened and how former combatants have negotiated their identities. Is there still a sense of Acehnese nationalism, as they fought for, and how has this intersected with their Indonesian nationalism since they became ordinary citizens?
\end{abstract}

Keywords: combatants; political identity; Acehnese nationalism; Indonesian nationalism; social citizenship

\section{INTRODUCTION}

Anti-Indonesian sentiments were central to the propaganda efforts of Gerakan Aceh Merdeka (Free Aceh Movement, GAM), a group established by Hasan Tiro by decree on December 4, 1976 (Hamzah 2014). Intended to promote justice and improve welfare in Aceh, this movement rapidly gained the support of Acehnese youths disappointed in the Indonesian government and its perceived tyranny and injustice. The massive economic gap between the people of Aceh and Indonesians outside Aceh, particularly on Java, was only one reason cited by GAM in its fight for Aceh's independence from the Unitary Republic of Indonesia. GAM claimed to be an autonomous authority, function as its own state, complete with its own government, flag, and armed forces (Tentara Nasional Aceh or the Aceh National Armed Forces). Although not all Acehnese agreed with GAM's claim, this situation still meant that Acehnese ethnonationalism clashed with Indonesian nationalism. GAM, born from ethnic sentiments, found fertile soil in Aceh, as decades of State neglect and injustices had promoted anti-Indonesian sentiments (Wiratmadinata and Putra 2016). As a result, many Acehnese did not consider themselves part of Indonesia, holding that the country had failed to provide a 'comfortable home' for the Acehnese people; as such, the Acehnese created their own home through primordial bonds (Latif 2004) - even though Aceh had been an integral 
part of the Indonesian struggle for independence and contributed significant material resources to the nascent Indonesian republic.

The ethno-nationalistic struggle in Aceh (1976-2005) involved not only men, but also women. At the end of 1990, the military wing of GAM created a women's unit known as the Inong Balee Troops (Pasukan Inong Balee, PIB), Askariyah/Askarimah, or Tjoet Njak Dien Troops (Hamzah 2014: 545). Women, girls, and widows, some 2,000 to 2,500 in number, joined PIB and fought in the forests and the mountains. For several months, they received military training and ideological reinforcement as they sought to gain Aceh's independence. They courageously, without any fear, became involved as combatants. They collected intelligence and secured GAM's logistics. Their participation as combatants was driven by their desire to gain independence and sovereignty, as they saw Indonesia as cruel, unjust, and not respecting the dignity of the Acehnese people.

After more than 29 years of conflict, in August 2005 the Indonesian government and GAM ultimately reached a peace agreement in Helsinki and ended the conflict. Aceh was again reintegrated into the Unitary State of Indonesia and gained Special Autonomy. Today, Aceh - particularly its capital Banda Acehonly has a few traces of the conflict and the tsunami. Physically, it is little different than other parts of Indonesia, where development and construction are underway. It is interesting to examine the Acehnese national identity, which was once strong enough to provoke armed conflict against Indonesia. Is such an identity still to be found, and has it transformed? This paper attempts to answer this question through an investigation of the women who had previously fought alongside men in GAM. Here, the term women combatants covers "all those who are found to be members of an armed force or group, whether they were involved in active combat or in support rolessuch as cooks, porters, messengers, administrators, sex slaves and "war wives" (UNDDR 2006).

Discussion of Acehnese political identity and nationalism is highly relevant, particularly since peace was reached. Congruent with post-peace development processes, as well reconstruction after the earthquake and tsunami, there has been an accumulation of capital by governments, private sector enterprises, foreigners, and members of society. The accumulation of capital has been vulnerable to competition and imbalances similar to those underlying the previous ethno-nationalistic. Efforts to win the "hearts and minds" of the people of Aceh and reintegrate them into Indonesia have required not only physical welfare, but also the development of a plural system for nationalism and citizenship that covers both Indonesian citizenship and Acehnese nationalism. Post-modern conceptualizations of citizenship recognize 'differential' (Rizman 2001) or 'social citizenship', which views nationalism as 'sharing a feeling of belonging' - a shared identity — as well as a 'sense of belonging' within a group or community.

This paper uses a qualitative narrative approach, drawing on the experiences of five women who had been combatants with GAM. All of the informants are former PIB members who, together with other GAM members, received military training and ideological indoctrination. The qualitative narrative approach has been deliberately selected for its ability to understand lives within their social context (Elliot 2005). Through this approach, "a person can understand themselves as living through time, a human subject with a past, present, and future, made whole by the coherence of the narrative plot with a beginning, middle, and end" (Ibid p. 125).

A short description of the informants, identified with pseudonyms, follows:

1. Solechah (age 43), born in Bireun and living in Bireun/Banda Aceh. She recently completed her duties as assistant to the deputy governor's wife (serving from 2012 to 2017) in Banda Aceh. In Bireun, she operates an herbal clinic with her husband. In 2009, she attempted to run for legislature, failed; she is still active in the Aceh Party (Partai Aceh, PA) and head of the Inong Balee Committee for Bireun. Solechah joined PIB at age 14 (in 1990) furtively. Although her parents supported the DI/TII (Darul Islam/Islamic Armed Forces of Indonesia) movement, they were opposed to her joining GAM and considered her too young; also, few women had joined by that point. After a year as a guerilla, she married a GAM leader, with whom she fled Aceh for Malaysia several months later and had four children. After her first husband's death in an attack by Indonesian security forces in 2004, she has remarried

2. Zulaikha (36), born and raised in Bireun, and is now an honorary staff member of the Shariah Office and the Agency for Protecting Peace in Aceh (Badan Penguatan Perdamaian Aceh, BP2A). Furthermore, she is also active in the 
rice fields and orchards, raises cattle with her mother, and serves as deputy secretary for the PA in Bireun. In 2012 she ran for legislature with the party, but was not elected. She also serves as treasurer for the Inong Balee Association of Bireun. She formally joined PIB in 1998, at age 17. However, she began providing assistance to GAM since her third year of elementary school, delivering food and cigarettes to their camps in the forests. Her family had dedicatedly supported Aceh Merdeka, GAM's predecessor. Her mother supported GAM in logistic issues, while one of her uncles was the supreme commander of GAM and killed in 2004. When GAM left the mountains and forests, her parents' home frequently became the site of leadership meetings. Zulaikha was a mualim and trained both male and female fighters.

3. Yunidar (37), living in North Aceh, and presently active in trade as well as the BP2A for North Aceh. She is also a member of PA, involved in various government programs for women (such as the Family Welfare Program and Taklim Council), and involved with the Indonesian Women's Coalition, in the activities of which she frequently represents North Aceh. Yunidar joined PIB in 1998, at the age of 18, after learning the ideology of Aceh Merdeka and GAM from her family, who supported the movement. She also frequently listened to the speeches of GAM leaders and supporters (including some former Indonesian soldiers) in her village. Yunidar provided intelligence, and was an active member of the volleyball team started by the Indonesian security forces in North Aceh.

4. Nurmala (47), born and raised in Bireun. As with Zulaikha and Yunidar, she is involved in the PA administration, family welfare group, and women's prayers group in her village. With Zulaikha, Nurmala is an active fundraiser for Inong Balee Committee activities in Bireun. Having joined GAM at age 25, she is the only informant who joined after becoming widowed and having a child. Although she did not complete elementary school, she was recognized for her courage and her willingness to fight. While a PIB member, she had many duties, including logistics and fundraising. She was frequently hunted by the Indonesian security forces. As a result, her brotherdespite not being in GAM-was tortured by the Indonesian security forces, while her child was repeatedly moved between family members' homes to avoid capture.

5. Aisyah (37), of Aceh Besar, is an honorary staff member of the Aceh-level BP2A. Every morning, before leaving for work, she helps her mother prepare nasi lemak (a type of rice dish) to sell near their home. She became a PIB member at age 17, after graduating from vocational school. She was motivated to join GAM because her home was frequently used by local GAM leaders for meetings. Her brother was one of the founders of the local GAM unit, and Aisyah was intrigued by the courage and machismo of her brother and his comrades, who travelled while bearing arms and wearing camouflage. After she finished her vocational studies, her brother offered her to study at a 'university in the forest' (i.e. join GAM); she agreed. Aisyah later became a mualim, training other female fighters. Furthermore, her father and younger brother also joined GAM.

\section{DISCUSSION \\ Women in the History of Aceh}

For centuries, women have been an integral part of Acehnese history. They have taken roles as government leaders as well as military commanders. Many dedicated themselves to the eradication of Portuguese and Dutch colonialism, even sacrificing their lives. They included Laksamana Malahayati, Cut Nyak Dien, Cut Meutia, Pocut Baren, and Pocut Meurah Intan (Aries et al. 2010). Stories of their heroism have retained the power to motivate young Acehnese women, even centuries later. During the Aceh conflict, these young women took up arms and became integral to GAM's fight against the Indonesian government. On average, these young women (married, unmarried, or widowed) were between the ages of 14 and 25 , had received some education (elementary, junior high, or senior high school), and came from rural areas. Literally translated, the term Inong Balee refers to widows and other women whose husbands have left them. However, within the historical context of Aceh, the term refers to women whose husbands were killed while fighting against invading forces. It refers to those widows led by Laksamana Malahayati, the military commander 
during the reign of Sultan Al Mukammil (1589-1604) who successfully fought back the Portuguese armada. ${ }^{1}$ This name was later repurposed by GAM's military commander, the late Tengku Abdullah Syafei, for the female unit (askariyah) established in 1989. ${ }^{2}$ This paper will use the phrase "member of the Pasukan Inong Balee" (PIB member) to distinguish between active combatants and women whose husbands died in the conflict.

History also records women as being involved in the more recent conflict between the people of Aceh and the country of Indonesia. These women were not the 'blue bloods' of the colonial era, but rather members of common society. Although they fought actively in the conflict, they received little attention and recognition aside from brief write-ups in social media. It is thus difficult to ascertain how many women were actively PIB members as no records (enrolment, membership, casualties) exist. In its most recent update, the Crisis Prevention and Recovery Unit of the United Nations Development Programme in Indonesia, gives 2,021 total membership (UNDP, July 2008). Meanwhile, the Working Group on Gender gives 1,630 members (KKG, March 2007). The intelligence unit of the Indonesian armed forces gives a much smaller number, only 200-300, spread throughout Aceh (Musrifah et al., 2015). One woman, who advised GAM during the peace negotiations in Helsinki and currently leads the League of Inong Balee (Liga Inong Balee, LINA), gives a figure of $2,000,{ }^{3}$ while a PIB member who helped establish the Inong Balee Committee in Bireun provides an estimate of 2,500. If GAM's had total membership of between 20,000 and 30,000 fighters, $10 \%$ were thus women.

From the documentary photographs and personal stories shared on social media and collected in books, it is readily apparent that these women fighters were active GAM fighters. Women voluntarily joined through either recruitment processes or through self-enrollment. Most participated in training, as with the men. After receiving this training, they were sworn into GAM by local movement leaders. GAM required women to obtain their parents' permission before joining, and many parents expressed pride when their daughters did join. Similar to male fighters, they received military training, covering physical fitness, political ideologies, religious doctrine, intelligence collection, and international humanitarian law. ${ }^{5}$ They wore military uniforms, bore arms, and lived in the mountains and forests of Aceh for months, always ready to relocate to avoid attacks by the Indonesian security forces in Aceh.

\section{Combatants' Motivation for Involvement}

National identity is a 'political claim' that shows loyalty, concern, and solidarity (Brubaker 2004). GAM claimed itself an autonomous authority, functioning as its own state, complete with its own government, flag, and armed forces (Tentara Nasional Aceh or the Aceh National Armed Forces). It created its own subjective understanding of ethnicity, 'a perspective on the world' (Brubaker et al. 2004), and created a movement based on Acehnese ethno-nationalism (involving both 'race' and 'nationhood'). In this context, GAM followed the precept that "a nation exists when a significance number of people in community consider themselves to form a nation, or behave as if they formed one" (Watson 1977, p. 5).

The involvement of women as GAM combatants is inexorably linked to the socio-cultural and religious situation in Aceh. This included their identification with Acehnese identity and the ethnonationalistic struggle, which was strongly believed, perceived, or understood (Brubaker et al. 2004).

"... so because, well, I saw the conditions in Aceh as they were then, and many women were taken (by the security forces) and raped. So I didn't accept this, and my passion for the fight was stirred. In the end I went up the mountains, trained, ... like that." (Zulaikha) ${ }^{6}$

This research has found that informants considered their Acehnese identities and sense of Acehnese ethno-nationalism to be their main reason for becoming PIB members. For them, joining GAM meant promoting an ethno-political struggle against the injustices perpetrated by the (non-Acehnese) Indonesian government; a struggle to restore cultural and religious values; and a struggle to realize the Acehnese independence. This ethno-nationalistic understanding was conveyed through schools as well as prayer meetings at the village meunasah (town hall/house of worship) that were sponsored by GAM and its sympathizers, including some members of the Indonesian armed forces. Islam, an integral part of Acehnese identity and culture, was the main justification for this ethno-nationalistic ideology (Abdullah 2017) and motivation for action (Razali 1982). In some more extreme cases, persons considered "un-Islamic" (particularly the Indonesian 
government and the Indonesian people) were branded as kafir, or non-believers. Some examples of respondents' expressions of ethno-nationalism are presented below:

It was because I'd heard the story of Cut Nyak Din. There were history books in school, before, and they told us of Tjoet Nyak Din, Tjoet Meutia, all those great people. I really wanted to be like that. Before we had GAM, it was Aceh Merdeka (Solechah) ${ }^{7}$

We are Acehnese. Before, there was freedom. In 1945, when Soekarno (Indonesia's first president) came here, he asked our help. Only we Acehnese could help. We bought two airplanes. Afterwards we were tricked. How can we finish things, make them like under Iskandar Muda? We must not always be deceived by these people (by Indonesians) ${ }^{8}$

Hmm... essentially, well... Aceh, it's so independent. Shouldn't be part of the Indonesian Republic anymore. How could we release ourselves, become free from the Indonesian Republic? ${ }^{9}$

My family was involved first. And then there was an Indonesian soldier who became involved too. And from there we got the ideology and awareness of the importance of defending our country. At the time, our knowledge wasn't like now, but we'd seen and heard the injustice. Felt it. And so we, yeah, we women had our minds opened. How could we free our people from the shackles of occupation? Yes, they aren't the same as the Dutch colonials before, but the current occupying force (Indonesians) might be more sadistic than the Dutch. When Aceh Merdeka was first formed, we wanted the freedom. To free our people from the shackles of (Indonesian) occupation. That was our main goal. At the time, we were so certain that independence would be forthcoming. Even if we died, martyred in the fight, our children and grandchildren would enjoy the fruits of our struggle. ${ }^{10}$

\section{Reinforcement of Ethno-nationalist Struggle}

Training and fighting with the Acehnese armed forces, combined with their months of religious and ideological indoctrination, led to women having militancy, dedication, and strong ties between PIB members. Furthermore, these experiences while with the Acehnese armed forces increased women's sense of gender equality. PIB members considered themselves 'of equal strength to male military members because they could also attain high organizational positions' (Uning 2009, p. 11). The strength and pride of these young women was developed through their military training, no less intense than that received by men, and rooted in them not being victims (unlike most young Acehnese women) but fighting for justice and Acehnese independence.

The Acehnese political ideology of PIB was reinforced when they officially became part of the group. After joining, they received continuous physical training, as well as knowledge/skill building and ideological indoctrination (Jones 2016). This training produced shared experiences and symbols that further reinforced their bonds and unity. Such shared experiences and symbols are important elements of ethno-political movements (Berger and Luckmann 1966). In this paper, the shared experiences and symbols that reinforced their ethno-political ideology include physical, military, and ideological prowess; collective punishment; and collective oath taking and induction.

1. Physical, Military, and Ideological Prowess All PIB members gained physical, military, and ideological prowess through physical training and skill-building activities. Their training was similar to that of men, and included running, climbing ropes, jumping over hurdles, crawling, rolling, etc. It lasted for 1.5 to 3 months, during which time trainees awoke early in the morning and continued their activities until early evening, with breaks for dining and prayer. Trainers, particularly for the first generation, were senior (male) GAM members, including commanders and persons who received training in Libya. Some PIB members later became mualim, i.e. trainers for subsequent generations of fighters. During these activities, they used Libyan Arabic for their terms and signals. ${ }^{11}$ Once a week, they were taught to disassemble and assemble weapons, build bombs, and use meter-long wooden weapons. Troops wore military uniforms, bore arms, and lived in the mountains and forests of Aceh for months at a time, often relocating to avoid Indonesian security forces. 
2. Collective Punishment

During training, PIB members were divided into small groups or platoons called pasir, which consisted of 15-25 people. If a pasir member misbehaved or showed a lack of discipline, all members would be punished; in other words, the entire group would be punished for every individual infraction (Zulaeha). Punishments ranged from push-ups and rolling for 100 meters (Yunidar) to bulee aree, bending over with one finger on the ground and then running in circles (Nurjanah). During training, women developed strong emotional bonds with their comrades, and they faced both happiness and sorrow together.

\section{Collective Oath-Taking and Induction}

After receiving training, PIB members swore oaths together in a massive ceremony. After reading the Quran and conducting ritual ablutions (wudhu), and without wearing any footwear, they would swear: "Darah Uloen, nyawong uloen, harta uloen, tuboh uloen, seuneuboh Nanggroe Aceh" (My blood, my life, my possessions, my body, only for Aceh). One senior Acehnese journalist, who frequently covered GAM ceremonies, stated that parents also participated in these ceremonies, which were held in open fields. Participants wore their best clothes, similar to those worn during holiday celebrations. ${ }^{12}$ Although PIB members were volunteers, many of their parents expressed pride at their joining.

The collective training and oath, shared guerilla experiences, and joy and sorrow, many PIB felt themselves inseparable parts of GAM. This had positive implications for their organization and its propaganda; with so many female soldiers, GAM received greater international attention and support. However, some women activists accused PIB members of serving solely as "accessories" (Kamaruzzaman 2008), particularly in propaganda. One activist, who had consulted with GAM, stated:

So, I see it like this. They have been shaping women not empower them, but just as part of a propaganda process. That's their (GAM) interest. For international relations..$^{13}$

The involvement of young women in the
Acehnese armed forces was certainly a powerful tactical move. Women, aside from replacing menwhose space for movement was limited under the Military Operations Area regime through Operation Red Net (Operasi Jaring Merah) in 1989-positively affected the organization's internationalization of its political and identity struggle. At the time, GAM attempted to show the international community that it fought for the Acehnese people, both men and women. However, it must be recognized that PIB members made conscious and voluntary decisions within a specific socio-cultural and religious context, one in which their non-traditional roles received appreciation and legitimacy. Building on the legacy of historical female Acehnese heroes, PIB members showed that women could contribute to the future development of Aceh and the Acehnese people.

\section{Identity Negotiations following the Helsinki Peace Agreement}

On August 15, 2005, the Helsinki Peace Agreement (also known as the Helsinki Memorandum of Understanding) formally ended the violent conflict between GAM and the Indonesian government. Aceh then received special autonomy status through Law No. 11 of 2006 and began the rebuilding process. Under this law, Aceh gained special political, economic, and socio-cultural autonomy, as well as the power to establish local political parties. Former GAM combatants used this opportunity to transform the previous armed conflict into a political one. As of the 2017 regional election, former GAM members have established two political parties: the Partai Aceh (Aceh Party, PA) and the Partai Nasional Aceh (National Aceh Party, PNA).

Since the signing of the Helsinki peace agreement, the peace process and rebuilding processes in Aceh has been dominated by men, particularly former GAM members. Such men have dominated economic development in Aceh, thus 'obtaining better economic incentives' (Ansori 2011) and 'receiving more tender for development, whatever the means' (Aspinall 2009). These men have also dominated the political sector; in the 2006 and 2012 regional elections, (male) former GAM were elected or appointed to executive offices at the provincial and regency level. In the 2009 legislative election, the Partai Aceh won 33 of the 69 available seats in the Acehnese parliament (Shahab 2012); of these, only 3 were occupied by women (Ansori 2015). Likewise, the 2017 regional 
election was dominated by former (male) GAM members, though they received fewer votes than in previous elections. Of the six gubernatorial/deputy gubernatorial pairs, five were former GAM members. In the election, the PNA candidates (Irwandi Yusuf and Nova Iriansyah) emerged victorious over the PA candidates (Mudzakir Manaf and T.A. Khalid).

Women have participated little in peacebuilding process in Aceh. In Helsinki, for instance, the Indonesian and GAM delegations had no women members as they negotiated. Meanwhile, neither the five main points of the peace agreement nor their elucidations mention female combatants/GAM supporters or their reintegration into Acehnese society. Instead, reintegration of both combatants and non-combatants has occurred naturally, without any specific aid programs; GAM supporters have returned to their families and assimilated into civil society. ${ }^{14}$ However, their participation and influence on political and economic development, both formal and institutional, has remained limited. Many have expressed concern for women's lack of participation in such processes (Frodin 2008, Basyar et al. 2008), arguing that women - particularly PIB membershave been marginalized during peace building efforts in Aceh (CMI 2006, Uning 2008, Oktaviana et al. 2014, Santoso and Yuniver S. n.d.).

What were the positive effects of peace on women, particularly those in the PIB? Informants stated that their situation has become much better, as they are no longer burdened by fear and anxiety but able to move about freely.

Now, things are good, because we're free. There's nobody coming at three at night. There are no more identity card checks. No more threats. That's how things are. The people are free. Since peace, the people have been free. (Nurmala)

Yeah, things are better during peace. When there was fighting, we had to hide. If we were seen, well... we had to see whether they (the security forces) were there. Now, things are free. (Zulaikha)

Actually, things have been better since peace, for both men and women... because now the children can go to school. Before the children lived in fear, and they weren't clever. If we were fearful during pregnancy, the children we bore wouldn't be clever either. That's the psychological aspect of it. (Solechah)

Feminist researcher Elise Boulding expresses an optimistic view about women's involvement in conflict and peace, writing that "women's knowledge and experience worlds have equipped them to function creatively as problem solvers and peacemakers in ways that men have not been equipped by their knowledge and experience worlds" (Boulding 2000, p. 109). Women's combat experiences can "transform their lives in terms of their image of themselves, their behaviour towards men and towards their elders, and their ability to live independently" (Sarosi 2007, p. 2). Although women have generally been (re)positioned in traditional domestic and maternal roles since the resolution of the Aceh conflict (Pankhrust 2003), PIB members have slowly negotiated their own positions and social roles, despite their individual limitations. Gender and power relations have not been transformed, nor has Acehnese political identity and ethno-nationalism. Nonetheless, the latter is no longer contrasted with Indonesian nationalism but redirected towards political and social activities promoting their groups' interests (specifically) in Indonesian development. Relations are more flexible, and produced through continuous negotiations.

This flexibility can be seen, for example, in their participation in the political processes in Aceh. They recognized the need to transform their struggle from armed guerilla warfare into open political contestation. ${ }^{15}$ They were also willing to descent from the mountains of Aceh, leave the forests, and surrender their weapons as a prerequisite for peace. Although they did not state it explicitly, their attitudes and actions indicated their willingness to again become part of Indonesia and maintain Indonesian citizenship. They recognized and obeyed the Helsinki Peace Accord, and also used their right to vote and become involved in the political parties established by former GAM members. The decision to become involved in GAMbacked parties is logical, given that their membership and networks was their sole remaining social capital after they stopped their fighting (Bourdieu 1990). They became actively involved in the local political parties established by former GAM members, which consolidated power and leadership from the regional (regency) to sagoe (village) level. Although they were only involved with local political parties, which nota bene were established by former GAM members, they did follow all of the election rules set by the Indonesian 
government. They were also willing to follow the different stages established by regulation. Zulaekha, for example, has served as the deputy secretary of the Aceh Party in Bireun Regency. ${ }^{16}$ PIB members have confidently and voluntarily become involved in campaigning and vote collecting. They focus on gathering women's support, thereby promoting their party's electoral success, and work on the front lines to gather their communities' sympathy. They happily visit different villages while wearing party attributes and distributing paraphernalia to women residents. This is important as, in Aceh, female voters in Aceh are roughly equal in number to male voters. According to the Acehnese Elections Commission, of the 3,443,583 registered voters in Aceh, 1,744,082 are women. Owing in part to their efforts, turnout rates for women voters reached $73 \%$. In this election, PIB members functioned not only as campaign staff, but also as witnesses at voting booths as votes were being tallied in the early morning.

Another example of their willingness to abide by the electoral regulations can be seen in the 2017 regional election. In this election, the GAMestablished PA (which they backed) was not victorious in the gubernatorial election; neither were most of their candidates for regent. This electoral defeat was highly disappointing for the party's supporters, particularly PIB, which had actively campaigned for it. Despite this disappointment, they continued to abide by electoral policy by filing their grievance to the constitutional court. They were also accepted the results after the constitutional court refused their case and declared Irwandi-Nova of the PNA victorious.

Regarding her learning the procedures and regulations for civilians, Solechah provided an interesting example. Her story, based on her experiences as the aid to the deputy governor's wife, illustrates the time and opportunities necessary for PIB members to become ordinary citizens. She mentioned that, after the armed violence ceased and the peace accord was signed, the PIB members who had recently descended from the mountains were highly arrogant. They would frequently travel to the pendopo (the governor's office) in search of financial assistance or projects. At the beginning, they were impolite and even forceful. Only later, after they learned the appropriate procedures for facing government officials and asking for support.

"Like, if she went to the governor's office, she'd be kicking them. Not anymore. There aren't any more PIB members going there... they're not wild when they go to the office. Don't insult people, because they (know) the procedures. They schedule it. Especially after I told them, don't go when it's time for meugang ${ }^{17}$, looking for money for meugang. It's shameful." ${ }^{\prime 18}$

Solechah, Zulaikha, and Aisyah ran in the 2014 regional legislative election. They recognized their candidacies as part of a broader political strategy to ensure male candidates' elections and to meet the $30 \%$ quota required by law. None, however, were elected. As they received no support from their party or their former GAM colleagues, they ran using their own resources. As a result, almost all former PIB who ran for local legislature experienced financial losses, up to and including bankruptcy. Aisyah and Zulaikha stated that they did not want to run in the 2019 election. Even though they had actively campaigned for PA candidates during the 2017 regional election, they were unwilling to present themselves as legislative candidates for the party. Their experiences of having votes for them "reallocated" to male candidates, as well as their material losses that went unremunerated, gave them strong reason not to run. Aisyah and Zulaikha expressed the view that the PA, as a continuation of the movement to which they had dedicated themselves, was unconcerned with their fates and had not truly supported their political participation. According to Aisyah, because of the material losses she incurred during the 2009 and 2014 legislative elections, she was not able to renew her lease on the shop she had been using to sell her wares. She was also unable to purchase any new wares, as she had sold them all to fund her campaign activities. ${ }^{19}$ Zulaikha, meanwhile, described how she had taken on debt for her campaign activities, including the printing of stickers and name cards, and yet the PA had taken the votes for her and reallocated them to a male candidate. ${ }^{20}$ Solechah, meanwhile, made a different decision. She stated that, during the 2019 legislative election, she would again be campaigning. However, owing to her disappointment in the PA, she would run with a different party, i.e. a national party with more resources. As of her interview, she had received offers to join the Great Indonesia Movement Party (Partai Gerakan Indonesia Raya, Gerindra) and National Awakening Party (Partai Kebangkitan Bangsa, PKB). She argued that campaigning for legislature was a worthy activity as, if she were victorious, she 
could give better opportunities to other former PIB members. $^{21}$

"I've got my own principles. For example, if I succeed, the Inong Balee also receive attention. If we're lacking capacity, we need to see it. We sometimes lack the capacity to promote welfare... it's all about how can think about those below us. I think about that. Like, here, why must it be (the PA), the opportunities here are limited. In the PA the opportunities aren't that quite good. If (other parties) give us chances and opportunities, then why not? Me, personally, that's what I think. My goal is to bring welfare to others too."

The political experiences of Aisyah, Zulaikha, and Solechah with the PA have shown the importance of in-group recognition and support for former PIB members. Although they had previously been an integral part of GAM, without any recognition or support they have begun to distance themselves from this group.

An identity negotiation process has been undergone naturally by PIB members through their social activities. All of the informants interviewed are members of their local family welfare groups (PKK), as well as informal leaders in local prayer groups for women. There is an interesting story related to these activities and how they adapted themselves to and learned the ritual of singing the Indonesian national anthem, "Indonesia Raya". This ritual is always practiced to open PKK meetings, particularly at the regency and provincial level. Initially, informants did not know that all present are required to stand when singing the anthem. As such, when they were first involved in this ritual they all sat in their chairs. At the next meeting, they learned that everyone was expected to stand, and as such they immediately stood when the anthem was sung. At this time, they noticed that many others were singing the Indonesian anthem, whereas they did not know it all and thus felt uncomfortable. Over time, they began to stand and mouth the words every time the anthem was played, even though they still had not memorized it. ${ }^{22}$ This story shows that it was not difficult for these former women combatants to accept new things as they learned to 'share a feeling of belonging', i.e. an Indonesian nationalism, no matter how symbolic. They simply needed time and the opportunity to interact with other groups and in other environments.

Everyday economic activities have also offered them the opportunity to interact with people from other groups. They have a 'shared identity', consciously or not, with other Acehnese women, as they must all seek income to be used to meet their household needs. Almost all informants (save Nurmala) work as honorary or volunteer staff at a government institution. Aisyah, Yunidar, and Zulaikha are honorary staff members with the BRA/BP2A at the provincial/regency level, while Solechah served as the assistant to the deputy governor's wife between 2012 and 2017. In informal employment, the women in Bireun are farmers, working their rice fields and other lands to supplement their everyday income. Meanwhile, Aisyah, who lives in the urban center of Aceh Besar, assists her mother in preparing nasi lemak (a rice dish) every morning for sale in local coffee shops.

Through the process of social and cultural interactions with others, particularly women from other groups, and as a result of the limited recognition and attention from their own group (i.e. [male] former GAM combatants), they have developed a sense of emancipation, which is manifested in their critical statements about the men and women around them. Aisyah criticized how female former GAM members gained minimal assistance, as well as access to executive and legislative offices in Aceh Besar. ${ }^{23}$ Zulaikha, meanwhile, rejected common perceptions - rooted in religious understandings and interpretations - that have hindered women's efforts to gain formal leadership positions in Acehnese society. ${ }^{24}$ Yunidar bemoaned how former PIB members were unable to integrate themselves with persons who were not in GAM, which has limited their movement and development potential. ${ }^{25}$ An awareness of their emancipation and the need to critically question authority and hierarchy has helped them make positive steps towards realizing women's agency in peacebuilding (Pankhrust and Pearce 1997).

The intensive involvement of PIB members in social relations and activities has ultimately enabled them to get in touch and know another identity: an Indonesian nationalist identity. Their first and the most important identity is their Acehnese national identity, which they have kept since the conflict, while their second identity - which emerged following the peace accord and their civil status as ordinary citizensis Indonesian (state) nationalism. This dual political identity has produced hope for a future without ethnonationalistic conflict or separatist movements and, more importantly, for using nonviolent approaches. 
Their awareness of their rights and responsibilities as citizens (of both Aceh and Indonesia) has made them more willing to give voice to the critical issues being faced by women, particularly former PIB members, as a marginalized group. As such, the Acehnese government, working with the Indonesian government, must find an approach where it is possible to win their "hearts and minds" by fulfilling their economic, social, and political rights and giving them a strong sense of social citizenship.

\section{CONCLUSION}

This paper is not intended to argue that an ethnonational struggle was sought by all of the people of Aceh. Rather, it emphasizes that this ethno-nationalism was one held by a certain group of people at a specific time. This paper is also not intended to state that ethnonationalism was women's only reason for joining PIB. Indeed, numerous rationales and motivations underpinned their enrolment, including the pressures of poverty, the lack of food, and the need for physical and mental security. Ethno-nationalism was but one of their motivations.

Since the peace accord, Aceh has offered former PIB combatants a safe place to move and act. This paper has shown that their freedom of movement, as well as their loss of concern for their physical and mental security, has offered them greater opportunity to transform their own social positions and roles by negotiating their political and ethnonational identity in the context of their own limitations. Their knowledge and experience as combatants has served them as important capital, as it has shown their leadership potential as well as reaffirmed their equal status with men. This important capital has then supported their involvement in everyday activities that reinforce their sense of community, both with other PIB members as well as with members of civil society.

This theme of negotiating ethno-nationalism and nationalism is interesting given that Aceh is presently transitioning into an integral part of Indonesia. Whether or not this reintegration succeeds depends on the extent to which post-Helsinki Accord developments can improve welfare and justice in society. At the same time, the experiences of PIB members as explored in this paper indicate that these identities need not always in conflict. Rather, they can be readily negotiated through everyday activities and processes that are both flexible and natural. This may provide input for activists, academics, and governments (both regional and national) as they design programs to promote and improve peacebuilding in Aceh.

Developing a sense of Indonesian nationalism will certainly take a long time. Such a nationalism can only develop where various (religious, political, social economic, etc.) groups there is a shared goal. In the context of the lengthy conflict between Aceh and the Indonesian government, this poses a considerable challenge. The experiences of PIB members show that women can also partake in debates over political ideologies and identities. Although they live in a context where their socio-cultural conditions (and religion) give greater emphasis to their traditional roles, their knowledge and experiences as combatants in the Aceh Conflict gave them important capital for negotiating their political identities.

\section{ENDNOTES}

1)http://m.news.viva.co.id/news/read/630874-acehdahulu-punya-100-kapal-perang, downloaded on 19 September 2015.

2)Facebook page "Inong Balee, Tentara Wanita GAM: Karena Balas Dendam dan Akibat Kekerasan”, downloaded on 19 September 2015.

3)Interview with SM, a GAM consultant during the Helsinki Accords, in Banda Aceh, May 2015.

4)Interview with Solechah, Banda Aceh, April 2015.

5)Jones Sirait, "Kemana Sang Inong Balee Pergi?"

Harian Umum Pelita, March 7, 2016.

6)Interview with Zulaikha in Bireun, 22 April 2017.

7)Interview with Solechah in Banda Aceh, April 2015.

8)Interview with Zulaeha in Biereun, April 2017.

9)Interview with Nurmala in Bireun, April 2017.

10)Interview with Yunidar in Banda Aceh, February 2016.

11)Example commands: alih wara = face left; tanzir $=$ go forward; isim salasa arba' = one two three.

12)Discussion with MH, Bireun, March 2017.

13)Interview with Cut Farah in Banda Aceh, 15 February 2016.

14)Focus Group Discussion with activists, Banda Aceh, 8 May 2015.

15)Interview with Aisyah, Aceh Besar, April 2017.

16)Interview with Zulaekha, Bireun, April 2017.

17)Meugang is a tradition in which people return to their homes with beef to cook for their families.

18)Interview with Solechah in Banda Aceh, 13 February 2018.

19)Interview with Aisyah in Aceh Besar, 25 April 2017.

20)Interview with Zulaikha in Bireun, 22 April 2017.

21)Interview with Solechah in Banda Aceh, 13 Februari 
2018.

22)FGD withAisyah, Zulaikha, Solecah and Nurmala in Yogyakarta, 21-22 August 2017.

23)Interview with Aisyah in Aceh, May 2015.

24)Interview with Zulaikha in Bireun, April 2017.

25)Interview with Yunidar in Banda Aceh, February 2016.

\section{REFERENCES}

Ansori, H. M. et al. (2015). Demokrasi pasca konflik, kekerasan dan pembangunan perdamaian di Aceh dan Maluku. Jakarta: Habibie Center and the National Violence Monitoring System.

Aspinal, E. (2009). Combatants to contractors: The political economy of peace in Aceh. Indonesia, 87(April), 1-34.

Aspinal, E. (2009). Islam and Nation: Separatist Rebellion in Aceh, Indonesia. Atanford: Stanford University Press.

Berger, L. P. and Luckmann, T. (1966). The social construction of reality: A treatise in the sociology of knowledge. London: Penguin Books.

Bertrand, Jacques. (2004). Nationalism and Ethnic Conflict in Indonesia. Cambridge: Cambridge University Press.

Boulding, E. (2000). Cultures of peace: The hidden side of history. Syracuse: Syracuse University Press.

Brubaker, R. (2004). In the Name of the Nation: Reflections on Nationalism and Patriotism. Citizenship Studies, 8(2), 115-127.

Budiawan (2017). Nasion dan Nasionalisme. Yogyakarta: Penerbit Ombak.

Crisis Management Initiative (2006). Proses Perdamaian Aceh: Keterlibatan Perempuan. Helsinki: Crisis Management Initiative.

Elliott, J. (2005). Using narrative in social research: Qualitative and Quantitative Approaches. London: SAGE Publications.

Frodin, L. (2008). The Challenges of Reintegration in Aceh. In Reconfiguring Politics: The IndonesiaAceh Peace Process, . Accord Issue 20, 54-57.

Ganelli, E. A. et al. (2010). Kepribadian Perempuan Aceh yang Tangguh: Kemarin, Sekarang danEesok. Medan: USU Press.

Hamzah, M. (2014). Hasan Tiro: Jalan Panjang Menuju Damai Aceh. Banda Aceh: Bandar Publishing.

Harker, R., Mahar, C. and Wilkes, C. Editors (1990). An Introduction to the Work of Pierre Bourdieu: The Practice Theory. London: The Macmillan Press.

Henshaw, A. L. (2017). Why Women Rebel: Understanding Female Participation in Intrastate Conflict. Dissertation, University of Arizona.
Seton-Watson, H. (1977). Nations and States: An Enquiry into the Origins of Nations and the Politics of Nationalism. London: Methuen.

Kamaruzzaman, S. (2008). Agents for Change: The Roles of Women in Aceh's Peace Process. In Accord Insight: Women Building Peace. London: Conciliation Resources.

Oktaviana S., Santoso, M.W. and Purwoko, D. (2014). Peran-peran Perempuan di Wilayah Konflik: Antara Korban, Penyintas dan Agen Perdamaian. Jurnal Masyarakat \& Budaya, 16(3), 383-397.

Pankhrust, D. and Pearce, J. (1997). Engendering the Analysis of Conflict: Perspective from the South. In H. Ashfar (Ed), Women and Empowerment. London: Routledge.

Rizman. M. R. (2001). The Relevance of Nationalism for Democratic Citizenship. The Public, 7(1), 5-14.

Santoso A. S. and Yuniver, S.F. (n.d.) Perempuan dan Perdamaian di Aceh (book draft). Banda Aceh: Mitra Sejati Perempuan Indonesia.

Shahab, S. (2012). Proses Negosiasi Pilkada Aceh: Studi Deskriptif Analitis Tentang Perubahan Sikap Partai Aceh Dari Menolak Menjadi Menerima Pada Pilkada Aceh 2012. Master's Thesis. National Defence and Conflict Resolution Department, Postgraduate School, Universitas Gadjah Mada.

Uning M. D. (2009). Female ex-combatants' Reintegration Into Post-conflict Aceh: Women at the Periphery. Unpublished paper.

Wiratmadinata, and Putra, B. Y. (2016). Nasionalisme vs Etnonasionalisme di Aceh. Banda Aceh: Bandar Publishing.

Yuval-Davis, Nira and Anthias Floya. Ed. (1989). Woman-Nation-State. New York: Palgrave Macmillan.

Sarosi, D. (2007). Human security: Does gender matter?" Retrieved from http://humansecurityconf.polsci. chula.ac.th/Documents/Presentations/Diana.pdf. 